\title{
HEPATOPROTECTIVE EFFECT OF FOREST HONEY ON CARBON TETRACHLORIDE INDUCED FEMALE WISTAR RATS
}

\section{EFEK HEPATOPROTEKTIF MADU HUTAN PADA TIKUS BETINA GALUR WISTAR YANG DIINDUKSI KARBON TETRAKLORIDA}

\author{
Yunita Linawati*) \\ Faculty of Pharmacy, Universitas Sanata Dharma, Campus 3 Paingan, Maguwoharjo, Depok, \\ Sleman, Yogyakarta 55282, Indonesia
}

Received February 20, 2018; Accepted April 30, 2018

\begin{abstract}
Hepatoprotective effect study of forest honey had been conducted on a female rat induced with carbon tetrachloride $\left(\mathrm{CCl}_{4}\right)$. The study aimed at obtaining the scientific data and the evidence of forest honey as hepatoprotective agent on the rat. The study was a true experimental study with a single factor completely randomized design. Thirty rats were randomly divided into six groups $(\mathrm{n}=5)$. Group I received carbon tetrachloride $2.0 \mathrm{~mL} / \mathrm{kgBW}$ intraperitoneally, group II received olive oil $2.0 \mathrm{~mL} / \mathrm{kgBW}$ intraperitoneally, group III received forest honey $8.1 \mathrm{~mL} / \mathrm{kgBW}$ (6 days, peroral), groups IV, V, VI were given forest honey $3.6,5.4,8.1 \mathrm{~mL} / \mathrm{kgBW}$ (6 days, peroral) and intraperitoneal induction of carbon tetrachloride $2 \mathrm{~mL} / \mathrm{kgBW}$ on seventh day. The blood sample of all rats were taken for ALT-AST measurement and their liver were sampled for histological examination of the liver cell. Groups I and III on the seventh day, group II on the second day, groups IV,V,VI on the eighth day. The result showed that a forest honey can be used as a hepatoprotective agent on the female rat Wistar strain induced by carbon tetrachloride 2 $\mathrm{mL} / \mathrm{kgBW}$ with doses $3.6,5.4,8.1 \mathrm{~mL} / \mathrm{kgBW}$.

Keywords: ALT-AST, carbon tetrachloride, forest honey, liver histopathology

ABSTRAK

Telah dilakukan penelitian efek hepatoprotektif madu hutan pada tikus betina terinduksi karbon tetraklorida (CCl4) dengan tujuan membuktikan efek hepatoprotektif madu hutan pada tikus galur wistar yang diinduksi karbon tetraklorida. Jenis penelitian ini adalah eksperimental murni dengan rancangan acak lengkap pola searah. Tiga puluh ekor tikus dibagi secara acak ke dalam enam kelompok ( $\mathrm{n=5}$ ). Kelompok I diberi karbon tetraklorida 2,0 $\mathrm{mL} / \mathrm{kgBB}$ secara intraperitoneal (i.p). Kelompok II diberi olive oil 2,0 $\mathrm{mL} / \mathrm{kg}$ BB secara i.p. Kelompok III diberi madu hutan 8,1 mL/kgBB (6 hari, peroral (p.o)); kelompok IV, V, VI diberi madu hutan 3,6; 5,4; 8,1 mL/kgBB (6 hari, p.o) dan diinduksi secara i.p dengan karbon tetraklorida $2 \mathrm{~mL} / \mathrm{kgBB}$ pada hari ketujuh. Kemudian dilakukan pengambilan sampel darah untuk diukur aktivitas serum alanin aminotransferase dan aspartat aminotransferase (ALT-AST) dan pengambilan organ hati untuk pengamatan histopatologi sel hati. Kelompok I dan III pada hari ketujuh, kelompok II pada hari kedua; kelompok IV, V, VI pada hari kedelapan. Hasil penelitian menunjukkan bahwa madu hutan memiliki efek hepatoprotektif pada tikus betina galur Wistar terinduksi 2,0 $\mathrm{mL} / \mathrm{kgBB}$ karbon tetraklorida dengan dosis 3,6; 5,4; dan 8,1 $\mathrm{mL} / \mathrm{kgBB}$.
\end{abstract}

Kata kunci: ALT-AST, karbon tetraklorida, madu hutan, histopatologi hati 


\section{INTRODUCTION}

Liver is the central organ in human body's metabolism system and it is very important for survival, both as a protection, detoxification, and even metabolism (Price, 2015). Liver could still maintain its function despite small damage because the existence of endogenous antioxidant helps the process of liver regeneration. On the other hand, a huge damage will cause imbalance between endogenous antioxidant and radical which will cause a quite massive liver disfunction (Jamilla et al., 2017).

The etiology of chronic liver disease that often happened in Asia includes: hepatotrophic virus and non-hepatotrophic, hepatitis $\mathrm{B}$ or $\mathrm{C}$ reactivation, infectious agent that grows in the hepar, alcohol, the usage of hepatotoxic medication, autoimmune hepatitis Wilson's disease) and surgery intervention, also the hepatotoxic etiology which have not been recognized yet (Sarin et al., 2009). One of the hepatotoxic material that had the potential to cause chronic liver disease was carbon tetrachloride $\left(\mathrm{CCl}_{4}\right)$. Carbon tetrachloride $\left(\mathrm{CCl}_{4}\right)$ was included into the list of hepatotoxic material that could produce radicals which is hidden in body fat, hepar, and backbone marrow. $\mathrm{CCl}_{4}$ caused hepar damages through stress oxidative reaction and biochemistry mechanism (Monika, 2012). The process of hepar damage caused by $\mathrm{CCl}_{4}$ induction could be prevented by antioxidant (Tjok and Wibawa, 2012).

Honey is one of the most popular natural resources that is frequently used as traditional medicine (Erguder et al., 2008). Honey contains fructose, glucose, and material that functions as antioxidant, like phenolic compound, chrysin, pinobanksin, vitamin $\mathrm{C}$, catalase, and pinocembrin (Chen et al., 2000; Nagai et al., 2006), and flavanoid compounds such as luteolin, quercetin, apigenin, fisetin, kaempferol, isorhamnetin, acacetin, tamarixetin, chrysin, and galangin (Erguder et al., 2008). It could be a form of remedy to some diseases, including heart disease. According to Erguder et al. (2008), honey is useful for preventing heart damages due to bile duct obstruction. Meanwhile, based on the research conducted by Mahesh et al. (2009), Indian honey could protect heart from oxidative damages and could be used as an effective hepatoprotector of heart damages due to paracetamol induction. In addition, research by Halawa et al. (2009) concluded that honey could modulate heart and kidneys' cell damages of a rat that was previously induced by lead. National Honey Board (2005), stated that one of the advantages of honey is that it is rich of antioxidant. Researches showed that honey is indeed a huge source of antioxidant. However, the quantity and the rate of antioxidant contained depend on the nectar's source. Darker-colored honey (e.g forest honey) is proved to have higher rate of antioxidant than lighter-colored honey (e.g. acacia honey) (Suranto, 2007). Therefore, forest honey is allegedly able to prevent heart damages. Up until this moment, there is still no research about the potential of forest honey as a hepatoprotection agent.

\section{METHODS}

The materials used in this research were forest honey sourced from the bees that could be found in Sialang trees located in Tesso Nilo National Park, Pelalawan, Riau, Sumatera. While the experimental animals were galur female Wistar rat weighed 100-200 grams and aged 1-2 months old collected from Hayati Imono Laboratory of the Faculty of Pharmacy Sanata Dharma University, Yogyakarta. Chemicals used were carbon tetrachloride, olive oil, aquadest, aquabidest, $\mathrm{NaCl} 0,9 \%$, formaldehyde $10 \%$, ALT and AST assay kits. The instruments used were beaker, measuring cylinder, volumetric flask, stirring rod, analytical scale, spoon, pipette, centrifuge, vortex, p.o and i.p syringes, hematocrite, Eppendorf $^{\circledR}$ cylinder, tweezers, scalpel, ointment pots, Microlab ${ }^{\circledR}$, and microscope.

The research protocol and procedures taken had attained approval from the Medical and Health Research Ethics Committee (MHREC) of Gajah Mada University's Faculty of Medicines. Thirty (30) experimental animals were randomly distributed into 6 treatment groups that each consisted of 5 experimental animals. Group I 
was given $2.0 \mathrm{~mL} / \mathrm{kgBW}$ of carbon tetrachloride material based on the i.p. Group II was given $2.0 \mathrm{~mL} / \mathrm{kgBW}$ olive oil based on the i.p. Group I and II's blood withdrawal was done after 24 hours. Group III was given forest honey with the dosage of $8.1 \mathrm{~mL} / \mathrm{kgBW}$ for six consecutive days based on p.o and the blood withdrawal was done on the seventh day. Group IV to VI were given forest honey (in order) $3.6 ; 5.4 ; 8.1 \mathrm{~mL} / \mathrm{kgBW}$ based on p.o once a day for six consecutive days. And on the seventh day, the groups were given carbon tetrachloride $2 \mathrm{~mL} / \mathrm{kgBW}$. Twenty four hours after carbon tetrachloride induction, $\pm 2 \mathrm{~mL}$ of blood was withdrawn through retro-orbital sinus method. Then, the activities of ALT and AST serums were measured (Utomo, 2015). Next, the rat was sacrificed as its liver was taken with the purpose of making its hepatology glass microscope slides. The ALT and AST serums' activities were analyzed using Saphiro-Wilk and continued by One Way ANOVA test with the confidence level of 95\%, and Post Hoc LSD test to discover the differences between each group. Hepar's hepatology examination's result was analyzed descriptively to find out the existence of possible damages and refinements on the cell.

\section{RESULTS AND DISCUSSION}

ALT and AST activities on the three dosages of treatment 3.6; 5.4; and 8.1 $\mathrm{mL} / \mathrm{kgBW}$ and $\mathrm{CCl}_{4}$ control group, olive oil control's data could be seen on Table I.

The research result showed that ALT serum's activities of forest honey treatment of $3.6 ; 5.4 ;$ and $8.1 \mathrm{~mL} / \mathrm{kgBW}$ were consecutively $78.40 \pm 20.54 ; 84.60 \pm 15.14$; and $60.80 \pm 8.14$ U/L (Figure 1). Based on Post Hoc LSD Test, the average of all groups' ALT activities of forest honey treatment was significantly different from $155.80 \pm 18.31 \mathrm{U} / \mathrm{L}$ $(\mathrm{p}<0,05)$ carbon tetrachloride control and insignificantly different from 52.00 $2.07 \mathrm{U} / \mathrm{L}$ $(\mathrm{p}<0.05)$ olive oil control. This result proved that $3.6 ; 5.4$; and $8.1 \mathrm{~mL} / \mathrm{kgBW}$ of forest honey could lower the activity level of ALT serums to the normal range. Based on the hepatoprotective percentage (Table I) of 3.6; 5.4 ; and $8.1 \mathrm{~mL} / \mathrm{kgBW}$ of forest honey consecutively scored $74.57 \% ; 68.59 \%$ and $91.52 \%$. This showed that hepatoprotective percentage possessed by the three forest honey treatment groups resulted near to the number of total healing which is $100 \%$.

Table I. The Effect of Applying Forest Honey on ALT and AST Serums' Activities of Carbon Tetrachloride-Induced Rats

\begin{tabular}{ccccc}
\hline Groups & $\begin{array}{c}\text { ALT } \pm \text { SE Averages } \\
(\mathrm{U} / \mathrm{L})\end{array}$ & $\begin{array}{c}\text { AST } \pm \text { SE } \\
\text { Averages }(\mathrm{U} / \mathrm{L})\end{array}$ & \multicolumn{2}{c}{ Hepatoprotective \% } \\
\cline { 4 - 5 } & $155.80 \pm 18.31^{\mathrm{b}, \mathrm{c}, 1,2,3}$ & $493.00 \pm 29.97^{\mathrm{b}, \mathrm{c}, 1,2,3}$ & - & ALT \\
\hline I & $52.00 \pm 2.07^{\mathrm{a}}$ & $99.00 \pm 4.85^{\mathrm{a}, 1,2,3}$ & - & - \\
\hline II & $49.40 \pm 6.25^{\mathrm{a}}$ & $108.40 \pm 9.71^{\mathrm{a}, 1,2,3}$ & - & - \\
\hline III & $78.40 \pm 20.54^{\mathrm{a}}$ & $389.40 \pm 70.38^{\mathrm{a}, \mathrm{b}, \mathrm{c}, 3}$ & $74.57 \%$ & $26.29 \%$ \\
\hline IV & $84.60 \pm 15.14^{\mathrm{a}}$ & $377.00 \pm 16.49^{\mathrm{a}, \mathrm{b}, \mathrm{c}, 3}$ & $68.59 \%$ & $29.44 \%$ \\
\hline V & $60.80 \pm 8.14^{\mathrm{a}}$ & $255.80 \pm 23.33^{\mathrm{a}, \mathrm{b}, \mathrm{c}, 1,2}$ & $91.52 \%$ & $60.20 \%$
\end{tabular}

Notes: I: $2.0 \mathrm{~mL} / \mathrm{kgBW} \mathrm{CCl}_{4}$ control; II: $2.0 \mathrm{~mL} / \mathrm{kgBW}$ olive oil control; III: $8.1 \mathrm{~mL} / \mathrm{kgBW}$ forest honey control; IV: $3.6 \mathrm{~mL} / \mathrm{kgBW}$ forest honey $+2.0 \mathrm{~mL} / \mathrm{kgBW} \mathrm{CCl}$; V: $5.4 \mathrm{~mL} / \mathrm{kgBW}$ forest honey +2.0 $\mathrm{mL} / \mathrm{kgBW} \mathrm{CCl}_{4} ; \mathrm{VI}: 8.1 \mathrm{~mL} / \mathrm{kgBW}$ forest honey $+2.0 \mathrm{~mL} / \mathrm{kgBW} \mathrm{CCl}_{4} ; \mathrm{SE}=$ standard error; $a=$ significantly different $(p<0.05)$ towards carbon tetrachloride control; $b=$ significantly different $(p<0.05)$ towards olive oil control; $\mathrm{c}=$ significantly different $(\mathrm{p}<0.05)$ towards forest honey control; 1.2 and $3=$ significantly different $(\mathrm{p}<0.05)$ towards forest honey $3.6 ; 5.4$ and $8.1 \mathrm{~mL} / \mathrm{kgBW}$ 


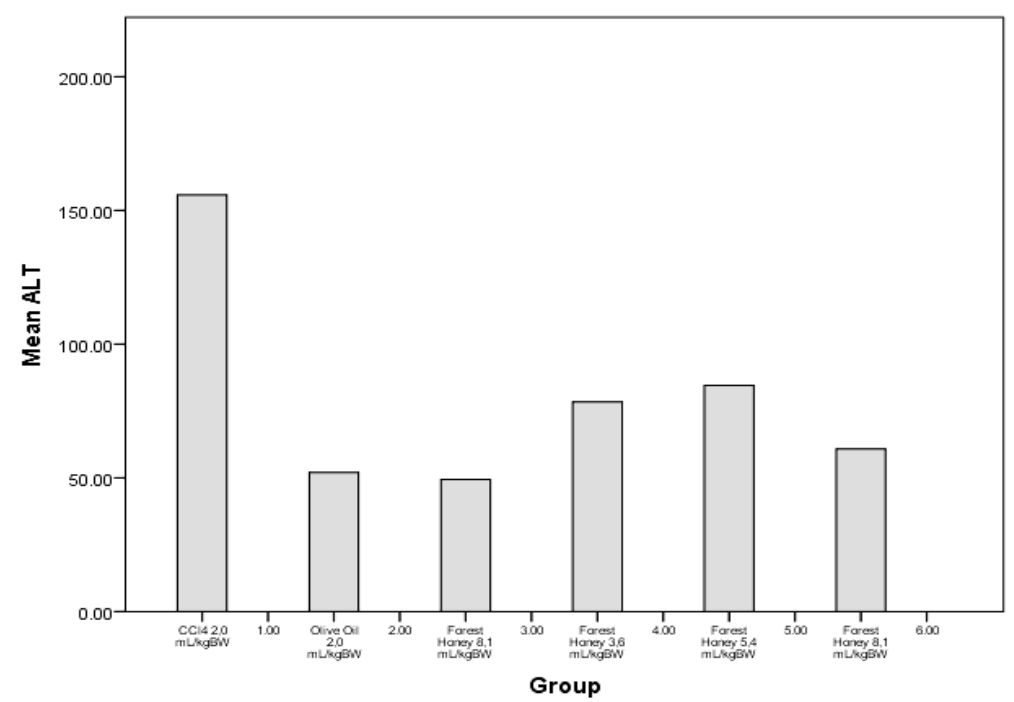

Figure 1. The effect of applying forest honey on ALT serum's activities of carbon tetrachloride-induced rats diagram

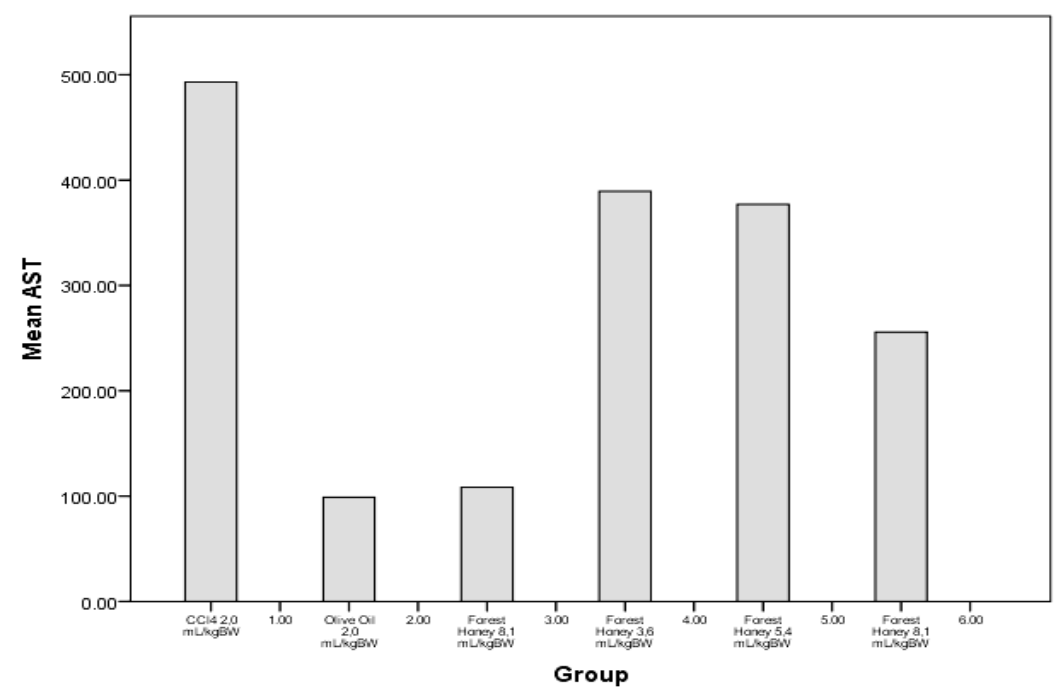

Figure 2. The effect of applying forest honey on AST serum's activities of carbon tetrachloride-induced rats diagram

AST serum's activities of forest honey treatment $3.6 ; 5.4$; and $8.1 \mathrm{~mL} / \mathrm{kgBW}$ scored consecutively $389.40 \pm 70.38 ; 377.00 \pm 16.49$;

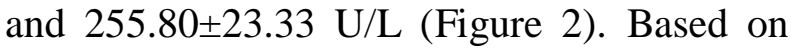
Post Hoc LSD Test, the average of all groups' AST serum activities of forest honey treatment was significantly different from $493.00 \pm 29.97$ $\mathrm{U} / \mathrm{L}(\mathrm{p}<0.05)$ of carbon tetrachloride control and from $99.00 \pm 4.85 \mathrm{U} / \mathrm{L}(\mathrm{p}<0.05)$ of olive oil control. This result proved that 3.6; 5.4; and $8.1 \mathrm{~mL} / \mathrm{kgBW}$ of forest honey could lower the activity level of AST serums but still have not succeeded to decrease the number into normal range. Based on the hepatoprotective percentage (Table I) of $3.6 ; 5.4$; and 8.1 $\mathrm{mL} / \mathrm{kgBW}$ of forest honey consecutively scored $26.29 \% ; 29.44 \%$ and $60.20 \%$. This showed that the hepatoprotective percentage possessed by the three forest honey treatment groups still have not reached close to the percentage of total healing which is $100 \%$. It was strengthened by a microscopic imagery of the rats' hepatocyte (Figure 3.a, b and c) which could be seen that on every forest honey treatment group, degenerative fattening still happened on the periportal space and around the veins on its hepatocyte cells. 


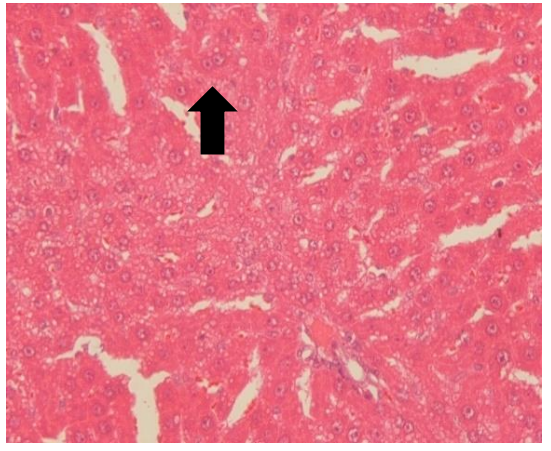

A

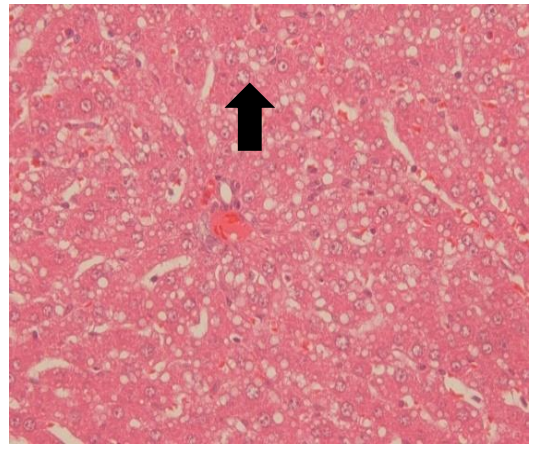

$\mathbf{B}$

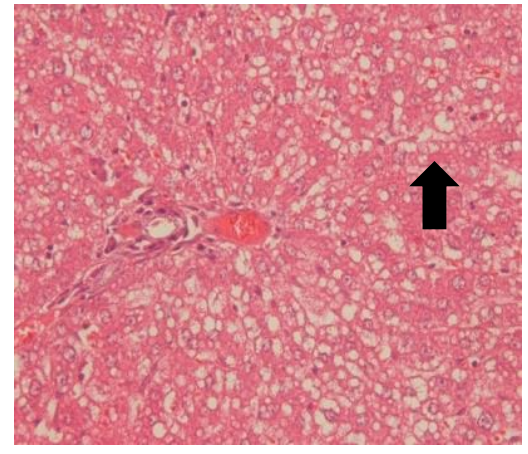

$\mathbf{C}$

Figure 3. Microscopic imageries of degenerative fattening on a rat's hepatocyte after applying forest honey of $3.6 \mathrm{~mL} / \mathrm{kgBW}(\mathrm{A}), 5.4 \mathrm{~mL} / \mathrm{kgBW}(\mathrm{B})$, and $8.1 \mathrm{~mL} / \mathrm{kgBW}$ (C).

The high-level AST serum's activities was caused by the existing damages on other organs such as the heart, muscles, and kidneys considering that AST is not specifically located in hepar only (Thapa and Anuj, 2007). Hepar is one of the most sensitive organs to exposures of carbon tetrachloride. However, it is still probable that carbon tetrachloride that was induced systematically based on i.p could cause damages on heart, kidneys, muscles, brain, and lungs.

According to the research, 3.6; 5.4; and $8.1 \mathrm{~mL} / \mathrm{kgBW}$ forest honey had the hepatoprotective effects since it could lower ALT and AST serums' activities level of carbon tetrachloride induced rats until it was significantly different from carbon tetrachloride. Honey contains fructose, glucose, and compounds which function as antioxidant, like phenolic compound, chrysin, pinobanksin, vitamin $\mathrm{C}$, catalase, and pinocembrin (Chen et al., 2000; Nagai et al., 2006), and flavanoid compounds such as luteolin, quercetin, apigenin, fisetin, kaempferol, isorhamnetin, acacetin, tamarixetin, chrysin, and galangin (Erguder et al., 2008). Kandimalla (2006) stated that flavanoid has the ability to serve as a hepatoprotective that could lower enzim (SGPT, SGOT, ALP, and LDH) serums on carbon tetrachloride induced rats. Flavanoid has a high electronegativity level which enables it to neutralize radicals by contributing hydrogen atoms to free electrons of $\mathrm{CCl}_{3}{ }^{-}$and $\mathrm{CCl}_{3} \mathrm{OO}^{-}$. It means that it is able to prevent any possible bonding between radicals and fatty acid located in hepar so that hepar damages can be resolved.

\section{CONCLUSION}

Forest honey on dosages of 3.6; 5.4; and $8.1 \mathrm{~mL} / \mathrm{kgBW}$ posessed the hepatoprotective effect on $2.0 \mathrm{~mL} / \mathrm{kgBW}$ of a carbon tetrachloride induced female rat Wistar strain.

\section{REFERENCES}

Chen, L., Mehta, A., Barenbaum, M., Zanger, A.R., and Engeseth, N.J., 2000. Honeys from Different Floral Sources as Inhibitors of Enzymatic Browning in Fruit and Vegetable Homogenates, Journal of Agricultural and Food Chemistry, 48(10), 4997-5000.

Erguder, B.I., Kilicoglu, S.S., Namuslu, M., Kilicoglu, B., Devrim, E., Kismet, K., and Durak, I., 2008. Honey prevent hepatic damage induced by obstruction of the common bile duct, World Journal of Gastroenterology, 12 (23), 37293732.

Halawa, H.M., El-Nefiawy, N.E., Makhloul, N.A., and Mady, A.A., 2009. Evaluation of Honey Protective on Lead Induced Oxidatives Stress in Rats, Journal of the Arab Society for Medical Research, 4 (2), 197 - 209.

Jamila, N., Khan, N., Khan, A.A., Khan, I., Khan, S.N., Zakaria, Z.A., Khairuddean, M., Osman, H., and Kim, K.S., 2017. In Vivo Carbon Tetrachloride-Induced 
Hepatoprotective and In Vivo Cytotoxic Activities of Garcinia hombroniana (Seashore Mangosteen). African Journal of Traditional, Complimentary \& Alternative Medicines, 14 (2), 374-382.

Kandimalla, R., Kalita, S., Saikia, B.,Choudhury, B., Singh, Y., Kalita, K., Dash, S., and Kotoky, J., 2016. Antioxidant and Hepatoprotective Potentiality of Randia dumetorum Lam. Leaf and Bark via Inhibition of Oxidative Stress and Inflammatory Cytokines. Journal Frontiers in Pharmacology, 7 (205), 1-8.

Mahesh, A., Shaheetha, J., Thangadurai, D., and Rao, D.M., 2009. Protective Effect of Indian Honey on Acetaminophen Induced Oxidative Stress and Liver Toxicity in Rat, Journal Biologia, 64 (6), $1225-1231$.

Monika, B., 2012. Propolis prevents hepatorenal injury induced by chronic exposure to carbon tetrachloride, hindawi publishing corporation, Evidence Based Complementary and Alternative Medicine, 2012, ID235358.

Nagai, T., Inoue, R., Kanamori, N., Suzuki, N., and Nagashima, T., 2006. Characterization of Honey from Different Floral Sources. Its Functional
Properties and Effects of Honey Species on Storage of Meat, Food Chemistry, 97, $256-262$.

Price, S.A., 2005. Patofisiologi konsep klinis proses-proses penyakit. Volume 1. Jakarta: EGC.

Sarin, S.K., Kedarisetty, C.K., Abbas, Z., Amarapurkar, D., Bihari, C., Chan, A.C., et al., 2009. Acute on-chronic liver failure: consensus recommendations of the Asian Pacific Association for The Study of The Liver (APASL) 2014. Hepatology International, 8(4), 453-471.

Suranto, A., 2007. Terapi Lebah, Penebar Plus, Jakarta.

Thapa, B.R., and Anuj, W., 2007. Liver Function Tests and their Interpretation. Indian Journal of Pediatrics, 74, 67-75.

Tjok, I.A.S., and Wibawa, I.D.N., 2012. Pendekatan diagnosis dan terapi fibrosis hati., Denpasar: Bagian / SMF Ilmu Penyakit Dalam FK Universitas Udayana / RS Sanglah.

Utomo, L.S., 2015. Efek Hepatoprotektif Pemberian Jangka Panjang Infusa Herba Bidens pilosa L. terhadap Aktivitas ALT-AST Serum pada Tikus Betina Terinduksi Karbon Tetraklorida. Skripsi. Fakultas Farmasi Universitas Sanata Dharma, Yogyakarta. 